Check for updates

London

Cite this as: $B M J 2020 ; 371: \mathrm{m} 4962$ http://dx.doi.org/10.1136/bmj.m4962 Published: 30 December 2020

\title{
Covid-19: Italian doctors are disciplined for anti-vaccination propaganda
}

Michael Day

An Italian doctors association has warned or disciplined 10 medics for promoting anti-vaccination propaganda and is considering sanctions against three others who are accused of downplaying the gravity of covid-19.

This comes amid growing concern that public scepticism over covid-19 vaccines could undermine Europe's fight against the coronavirus pandemic.

Antonio Magi, president of the Ordine dei Medici di Roma (Rome Doctors Guild), said that inquiries into 10 medics accused of unwarranted criticism of vaccinations had been completed, with punishments ranging from warnings to two month suspensions. The other three investigations were ongoing, he told the Ansa news agency. The disciplinary procedures followed complaints from other doctors and members of the public.

The three medics still under investigation will be asked to justify claims they have made online, on television, and on radio, to a special commission of the guild.

One of the three is Mariano Amici, who practices in Ardea, $30 \mathrm{~km}$ south of Rome. He describes himself as a practitioner of general medicine. He says that he is not against vaccinations as such, despite having some misgivings about the Pfizer-BioNtech vaccine that is now being given in Italy. On his website he says that he is "perplexed" about the health risks from such mRNA vaccines and questions whether they are appropriate for fighting a disease that he claims has a death rate of only one in 2000. ${ }^{1}$ Most estimates put the mortality rate 10 times higher.

Despite the investigation against him he has continued to make unsubstantiated assertions. Last week he declared, "The English variant of covid that is causing so much concern at the moment confirms what I have been arguing for months: the vaccine for a virus that has already changed so many times risks being ineffective and even dangerous."

\section{Scientific understanding}

Another medical organisation, the Italian Federation of Medical Professional Associations (FNOMCEO), has expressed concern over doctors who are refusing to be vaccinated.

FNOMCEO's president, Filippo Anelli, told the Italian media that around 100 medics were unwilling to receive the immunisation, adding that vaccine scepticism was "incompatible with the profession because it denied the scientific evidence."

Pierpaolo Sileri, Italy's deputy health minister and a professor of surgery, hit out at his vaccine sceptic colleagues. "I am perplexed when I hear of fellow doctors or nurses reluctant to get the vaccine," he said. "I can understand it regarding a member of the public who perhaps does not have the scientific understanding ... but frankly, I think that those doctors and nurses, if they still have doubts after seeing everything that's happened, are probably in the wrong job."

EU leaders are concerned that anti-vaccination sentiment could seriously undermine the continent's attempts to vanquish covid-19. In some countries, including Italy, Germany, Spain, and Sweden, public scepticism over covid-19 vaccines is thought to be high.

In France, the latest monthly poll by CoviPrev for Santé Publique France (the public health agency) found that only $40 \%$ of respondents said that they would consider getting vaccinated-and of those, only $13 \%$ said that they were "certain" to receive it. ${ }^{2}$

Meanwhile, Spanish authorities have said that they will compile a register of people who refuse covid-19 vaccinations, which they will share with other EU countries. Spain's health minister, Salvador Illa, said that the list would not be public and insisted that it would be compiled in "full respect" of people's privacy.

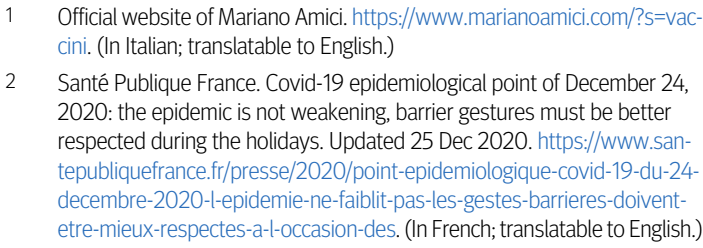
2020: the epidemic is not weakening, barrier gestures must be better respected during the holidays. Updated 25 Dec 2020. https://www.santepubliquefrance.fr/presse/2020/point-epidemiologique-covid-19-du-24decembre-2020-l-epidemie-ne-faiblit-pas-les-gestes-barrieres-doiventetre-mieux-respectes-a-l-occasion-des. (In French; translatable to English.)

This article is made freely available for use in accordance with BMJ's website terms and conditions for the duration of the covid-19 pandemic or until otherwise determined by BMJ. You may use, download and print the article for any lawful, non-commercial purpose (including text and data mining) provided that all copyright notices and trade marks are retained. 